\title{
Environmantal Ipact of Mining
}

\author{
Vojtech Dirner*, Eliška Kulová, Kateřina Polínková
}

VSB - Technical University of Ostrava, Faculty of Mining and Geology, Institute of Environmental Engineering, 17. listopadu 15, 70833 Ostrava Poruba, Czech Republic

\begin{abstract}
This paper deals with the impact of mining on the environment. Coal mining is still among the most widespread and most intense mining activity, which disturbs the landscape around us. For many countries, including the Czech republic, deposits of raw materials play an important role, especially for purposes of producing electricity and thermal energy. Part sof these problem are: the monitoring, environmental impacts assesment of exploration and mining activities and waste disposal mining, which may significantly contribute to the environmental protection in the future.
\end{abstract}

Keywords: Mining, environmental monitoring, environmental impact, landfill mining.

\section{Introduction}

Mining is a profession dealing with geological exploration, development work, mineral deposit mining, preparation of minerals, relevant construction as well as effacing of negative environmental impacts. Mining methods can be classified as:

- opencast (carried out in opencast quarries),

- underground (carried out in underground mines),

- others (e.g. geotechnological mining methods - chemical, bacterial leaching, etc.).

In terms of mineral deposit mining we distinguish coal, ore and industrial mineral (non-ore) mining.

The extraction of mineral resources is closely connected with negative environmental impacts. The manner and intensity of impact on the landscape depends on:

- the type of extracted raw material,

- mining method and its intensity,

- concentration of mining operations on a certain territory,

- geological conditions of deposit formation,

- morphology of the affected territories.

Coal mining is the most widespread and most intense mining activity that disturbs the landscape. In many countries, including the Czech Republic, deposits of energetic raw materials play an important role as power and heat generation is largely dependent on them. In the Czech Republic, negative impacts of coal mining may be observed in Podkrušnohorí and the Ostrava Region. Figures 1 and 2 show coalfields of the Czech Republic.

All major components of the natural environment are usually affected, such as soil, water and air. At the same time, especially in the localities with concentrated mining (e.g. Karviná part of the Ostrava-Karviná District - OKR) the landscape is affected as a whole and the so-called mining landscape originates. There are prominent changes in geomorphology, soil fund, greenery, atmosphere, hydrogeology 
and other biotic constituents of the landscape.

Soil is influenced in the most intense way, water is less affected and air comes last. Manifestations and impacts of opencast mining are completely different.

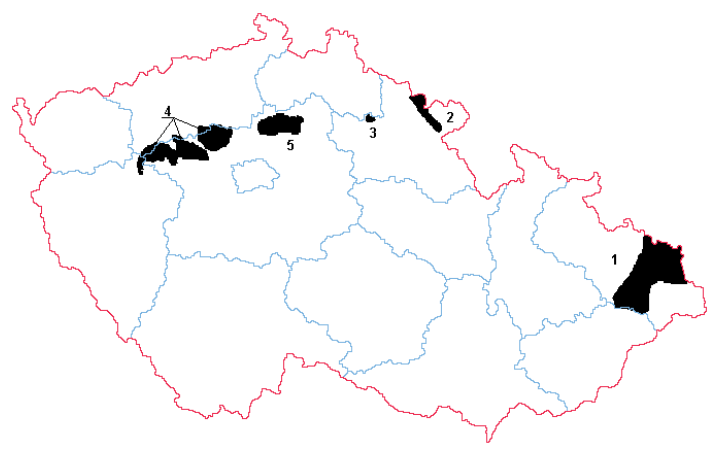

Fig. 1: Black coal fields in the Czech Republic: 1. Upper-Silesian $1600 \mathrm{~km}^{2}$ (predominantly in Poland), the only territory of current mining, 2. Inner-Sudetic - mined out, no more economic, 3. Lower Giant Mountains - low-quality coal, inperspective, 4. Central-Bohemian - mined out, no more economic, 5. Mělník - no more economic, inperspective.

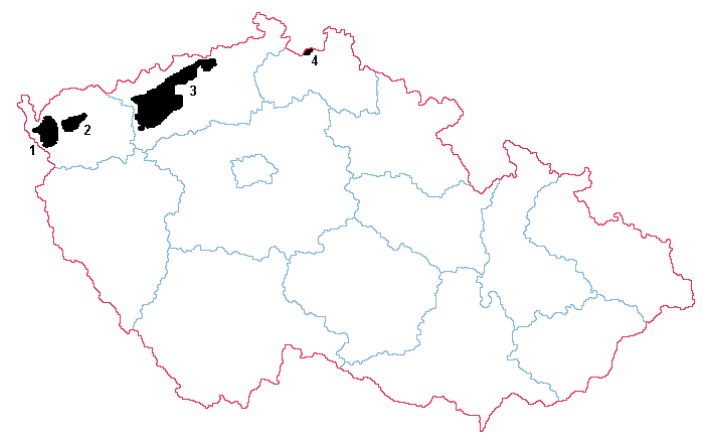

Fig. 2: Brown coal fields in the Czech Republic: 1. Cheb - it is not exploited with regard to the spa mineral water of Františkovy Lázně, 2. Sokolov - 25\% mining, 3. North-Bohemian - 3 parts (Chomutov, Most, Teplice), 75\% mining, opencast mining, 4. Žitavská - it is not exploited due to economic and technical reasons.

\subsection{Underground Mining}

Underground mining of mineral resources is manifested on the surface in the form of two characteristic elements, such as refuse dumps (waste rock) and movements and deformations caused by undermining. Refuse dumps influence the landscape and the environment in the negative way in many respects. They are atypical geomorphological formations in the landscape, especially when conical dumps are concerned. They are also the source of dustiness, both primary and secondary. In certain cases, when their ignition occurs they are sources of waste products polluting the atmosphere further afield. Dumps also usually take up fertile land. Their decontamination and reclamation is difficult, and depends on the shape and dimensions of the dump.

The second typical element are movements and ground deformations caused by undermining. Movements of the undermined territory cause the following:

- substantial, long-term and spatially extensive destruction of the relief, landscape, residences, underground services, roads, in the sites of subsidence basins hazardous disposal sites of industrial and municipal waste are concentrated,

- irreversible changes in ground and surface water, formation of drainless inundated subsidence basins, changes in the courses of rivers and streams and their falls of stream, changes in the catchment ratios in the sewage systems,

- damage and destruction to the soil profile.

\section{The impacts of undermining}

The overall extent of undermining impacts depends on, in particular:

- intensity and character of mining impacts,

ground morphology,

- structure, type and character of premises, facilities and soils found in the mining landscape.

Undermining shows in the long-term and, to a certain extent, cyclically. The cycle of the manifestations of undermining can be divided into three stages as for biotic action, according to Smolík, as shown in Table 1.

Undermining is manifested both by the movement of rock massif in the surroundings of the worked out space and the rock massif in the main roof, as well as by the movement all the way to the ground, i.e. having an effect on the morphology of landscape.

The manifestations of undermining on the landscape morphology can be diverse. Basically, they are divided into continuous and discontinuous deformations.

The character of earth ground deformation predominantly depends on a number of factors that can be classified as follows:

- geological factors (geological structure, degree of tectonic ruptures, hydrogeological conditions), 
Table 1: Stages of the effect of undermining on the environment.

\begin{tabular}{|c|c|c|c|}
\hline Stages & Type & Environmental components & Manifestations \\
\hline 1 & impacts of undermining & $\begin{array}{l}\text { rock massif and landscape } \\
\text { relief }\end{array}$ & $\begin{array}{l}\text { subsidence, movements, delevelling, curvature, } \\
\text { proportional horizontal deformations, disconti- } \\
\text { nuous deformations, etc. }\end{array}$ \\
\hline 2 & $\begin{array}{l}\text { consequences of impacts } \\
\text { of undermining }\end{array}$ & $\begin{array}{l}\text { landscape and its consti- } \\
\text { tuents (anthropogenic } \\
\text { sphere, pedosphere and } \\
\text { hydrosphere) }\end{array}$ & $\begin{array}{l}\text { subsidence, lifting, shifting, expansion, compac- } \\
\text { ting, tilting, change in the gradient, waterlo- } \\
\text { gging, flooding, degradation, devastation, etc. }\end{array}$ \\
\hline 3 & $\begin{array}{l}\text { removal and effacement } \\
\text { of the consequences of } \\
\text { undermining }\end{array}$ & $\begin{array}{l}\text { landscape and its consti- } \\
\text { tuents }\end{array}$ & $\begin{array}{l}\text { repairs, decontamination, reclamation, regene- } \\
\text { ration, liquidation, demolition }\end{array}$ \\
\hline
\end{tabular}

- geomechanical factors (geomechanical properties of rocks),

- spatial factors (depth of mining, deposit dip, shape and dimensions of the worked out space, deposit thickness, landscape morphology),

- operating factors (technology of mining, filling method of the worked out space, failure to the roof due to earlier winning operations),

- time factors (formation rate of area of extraction, rate of overburden subsidence).

Continuous deformations are characterized by gradual formation of a continuous subsidence ba$\sin$, the shape of which is usually given by the dip of the worked deposit (inclined and steep dip) and the depth of extraction.

Discontinuous deformations of the ground are characterized by exceeding the soil or rock strength. Among the forms of discontinuous deformations there are - ground degree, cracks, ground roll, earth fall and downthrows. Discontinuous deformations of the ground are accompanied by structural changes in the foundation soil the tensile, compression and shearing strength of which is exceeded. Discontinuous deformations of the ground usually form very fast, which on the other hand does not permit the use of rheological characteristics of building materials or foundation soils. For premises on undermined territories, discontinuous deformations are more dangerous than the continuous ones. Their influence of the landscape morphology is destructive.

Therefore, periodic measuring is carried out in undermined territories. Movements and deformations are measured in observations bases which are stabilized both in the terrain as well as in sensitive premises and facilities in the mining landscape.
Among the main environmental impacts of underground mining there are:

- dumps (dustiness, burning, washing away of sulphur),

- mining areas (gas bursts, ventilation outlets, etc.),

- concentration of industrial and municipal waste disposal sites,

- irreversible changes in water regime - formation of drainless areas,

- damage and destruction to the soil profile.

\subsection{Opencast Mining}

Among the major consequences of opencast quarrying of mineral resources for the environment there are:

-long-term and frequently irreversibly claimed land with high-quality agricultural and forestry soils that are locally accompanied by devastation of rare wetland ecosystems with protected species of flora and fauna,

- changes in the landscape relief, including dumps, clearance, interfering neologisms are formed, exceptionally complete devace are removed - landscape dominants,

- threat to the drinking water reserves bound onto the rock formations with all negative manifestations (contamination, reduction in the ground water level, interference with the natural circulation),

- formation of water areas that may locally cause irreversible microclimatic changes,

- the surroundings of mining operations are strained with increased noise levels and dustiness (e.g. the effects of blasting, transport of raw materials),

- development of related industry - power engineering, chemical industry. 


\section{Environmental Issues of Deposit Exploration, Mining and its Termination}

Geological conditions and processes condition the character of the anthroposphere to a great extent, where the effects of mutual action of the geosphere, hydrosphere, atmosphere and biosphere with human activities present. Therefore, for a number of years the so-called environmental geofactors have been monitored and evaluated in the form of special maps, among which there are mineral resource deposits, ground water sources including such for medical purposes, geotechnical and geochemical characteristics of the environment, soil conditions, geodynamic phenomena, etc., i.e. factors that are important in providing for the human material needs and in the formation of the environment. In this respect, a geological exploration has a cognitive, appraising and informative function. Deposit exploration and especially consecutive extraction and modification of the discovered deposits of mineral resources may have a range of impacts on the natural, social and economic environment. In the sphere of the natural environment it predominantly influences the rock environment as well as other constituents of the environment (hydrosphere, atmosphere and biosphere). The movement of masses connected with the extraction is huge and in its extent it significantly exceeds the share of natural processes. Thus, a lot of attention has been paid to monitoring and evaluation of environmental impacts of mineral resource industrial activities. However, it must be emphasized that the impact of mining plant activities has a local or maximally regional character only, as for the affected area of a region or state, for example, it is practically negligible. For instance, between 1930 and 1980 mere $0.25 \%$ of the overall area of the USA was used for opencast mining, dumps of opencast and underground mines and waste disposal sites from preparation plants. All mines for non-ferrous metals take up only 0.02 $\%$ of the area. Concurrently, approximately $47 \%$ of the area affected by mining and waste dumps was reclaimed as per the end of the stated period (Johnson et Paone in Ostensson 1997). In Australia the area affected with mining activities concerns a completely negligible number of $0.001 \%$. With no doubt, there are other activities with much more extensive and serious impacts, such as powerengineering, automobile transport, agriculture or timber cutting in tropical rain forests (Table 2). Nevertheless, e.g. deposit territories of opencast mining of coal, iron or porphyry copper ores deserve some attention.

Table 2: Human activities and possible environmental impacts.

\begin{tabular}{|l|l|l|}
\hline Sphere of activities & Possible environmental impacts & \multicolumn{2}{l|}{ Extent of impacts } \\
\hline power-engineering & $\begin{array}{l}\text { pollution of air, water and soil, thermal effects, damage to the biosphere, } \\
\text { agricultural and forestry land required }\end{array}$ & regional to global \\
\hline agriculture and forestry & $\begin{array}{l}\text { erosion, landslides, salting of soil, floods, pollution and changes in the water } \\
\text { regime, influenced biosphere }\end{array}$ & regional to global \\
\hline transport and waterworks & $\begin{array}{l}\text { landslides, rock falls, earthflows, subsidence, floods, changes in the ground } \\
\text { water levels, influenced biosphere, land required }\end{array}$ & regional \\
\hline industrial production & pollution of air, water and soil, noise, vibration, damage to the biosphere & local to regional \\
\hline mining & $\begin{array}{l}\text { changes in the landscape morphology, subsidence, landslides, reduction in } \\
\text { the ground water levels, pollution of air, water and soil, concussions, noise and } \\
\text { vibrations, damage to the biosphere, land required }\end{array}$ & local to regional \\
\hline housing development & $\begin{array}{l}\text { changes in the landscape morphology, pollution of air, water and soil, thermal } \\
\text { effects, noise, influenced biosphere, land required }\end{array}$ & local to regional \\
\hline tourism & pollution of water and soil, soil erosion, damage to the biosphere & local to regional \\
\hline waste disposal & $\begin{array}{l}\text { pollution of air, water and soil, impact to the underlying rocks, thermal effects, } \\
\text { land required }\end{array}$ & local \\
\hline transport & pollution of air and water, noise and vibrations, influenced biosphere & global \\
\hline waterworks engineering & impacted water regime, changes in the landscape morphology, subsidence & local \\
\hline geological exploration & \begin{tabular}{l} 
possible impact to the water regime and polluted water sources \\
\hline
\end{tabular} & local \\
\hline
\end{tabular}


It is apparent that the own geological exploration does not represent great danger for the environment. Both the impacts of the applied procedures are minimal as well as the valid regulations require disposal of the incurred interference with the environment immediately after work termination. More prominent are the impacts of mining activities that must be analyzed already within the survey. A part of the final report or the feasibility study of the mining plan must incorporate an assessment of expected impacts on all the environmental components and suggestions for their minimization and consequent disposal within termination work. During analyses, apart from the physical environment, the economic environment must also be respected, which has a comparable significance in assessing an exploratory and mining plan at least.

\section{Environmental Impact Assessment - EIA}

The process of assessing the impacts of exploratory and mining activities plays a positive role in the plan preparation. It makes part of the system of preventive tools of environmental protection and it appropriately complements the mining legislation. In its consequence, it leads to the minimization of financial costs for the programme implementation and related environmental measures. The introduced system of public hearing, which makes part of the assessment process, eliminates possible conflicts with the public. The screening process that is being introduced shall even improve the situation as the public will be involved in the assessment process already in the initial stage of the process.

The term of EIA - Environmental Impact Assessment - is grounded in National Environmental Policy Act of 1969 in the environmental domain, division 102.

This act brought a radical change as in the form of an Environmental Impact Statement (EIS), for the first time ever, a proposer of activity is obliged to prove that they will not significantly affect the environment.

The European Economic Commission stated in the Second Environmental Action Programme of 1977 that EIA is a requisite tool of environmental care. After numerous negotiations, in 1985 European Community Council Directive 85/337 was negotiated on environmental impact assessment of certain private and public projects. The next im- portant step was EEC convention acceptance on environmental impact assessment exceeding the national borders in 1991 (the so-called Espoo). The individual countries applied EEC Directive 85/1985 in three forms. Some countries incorporated the issue of EIA into the existing legal norms, usually as amendments on land-use planning (Great Britain, Ireland, Denmark) or acts on conservation of nature (France). In other countries EIA became part of acts on the environment (Netherlands, Greece). At last, some countries adopted separate legal norms on EIA (Germany, Belgium, Spain, Czech Republic and further to the provisions of the environmental law).

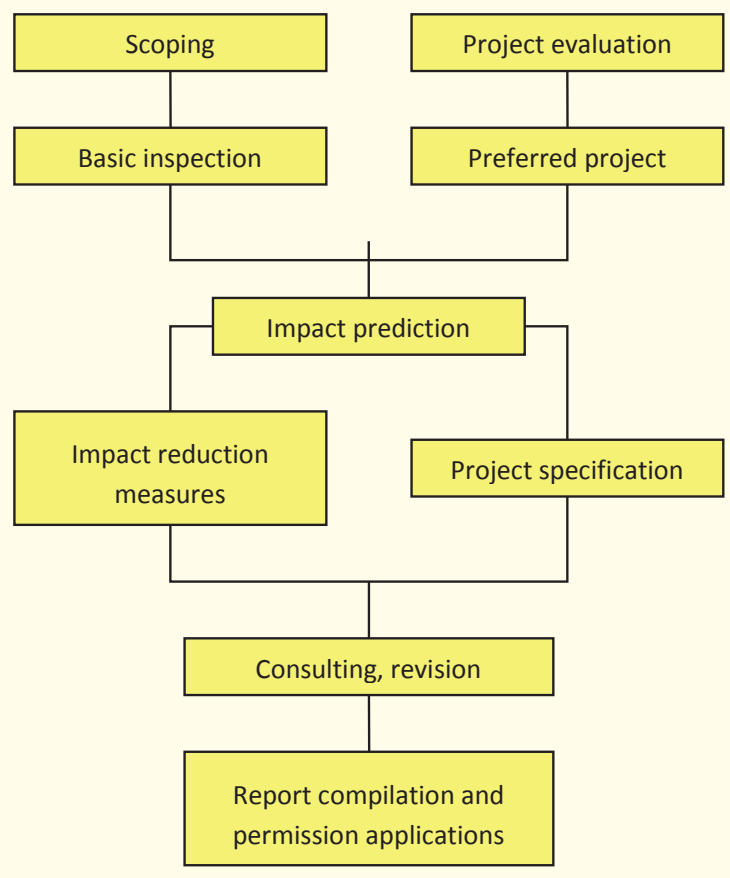

Fig. 3: Chart of ElA process, according to SRK Ltd.

Currently, assessment of constructions, activities and technologies, assessment of development concepts and programmes and assessment of products is under way. Procedures and required particulars differ in the individual groups. Projects are assessed in terms of ecological acceptability of the territory in question, consequences of the activities and possible accidents, cumulative and synergic phenomena, prevention and minimization of project's environmental impacts, disposal method of products after their expiration or utilization (pos- 
sible recycling and disposal), applied assessment methods and comprehensiveness of information. At the same time, a comparison with best available technologies is also required.

Along with the progress in the environmental legislation and requirements for ever stricter standards, environmental research is becoming a basic element of planning exploratory and mining programmes. It is ideal to start such work already in the initial stages of the project preparation in order to prevent incorporation of such activities which would lead to complications or fatal events or unsolvable conflicts of interest. The first stage of the task, which is compulsory in certain countries, is scoping as a precondition of development acceptability for the approving agencies and investors. The following stage of study and assessment of impacts and proposals of possible solutions arise in the mutual co-operation of an engineering and environmental team (Fig. 3).

As stated above, the programmes of deposit exploration do not have significant impacts on the environment. The majority of geological, geophysical and geochemical methods are non-destructive in their character. A certain impact is caused by the application of technical exploratory work connected with construction of access roads and workplaces, which may lead to damage on forest plantations and farm land. The use of drilling and underground mining work may influence water conditions due to discharge of mud and leaks of oil products. The circumstances are usually regulated by mining law that sets the duty of land reinstatement (if objectively and economically possible) and duty of surface exploratory work disposal and mine working securing. Exploratory programmes are also bound to relevant permits that may include implementation conditions in terms of environmental protection. Within exploratory programmes it is also necessary to follow another part of environmental protection, namely in terms of the final effect. It is not effective to implement exploratory work the results of which will not be applicable due to the environmental protection (e.g. deposits of building stone or gravel sand).

Environmental impact assessment is required for all activities connected with the exploitation of mineral resource deposits as they concern land, water sources, ecological systems, cultural and protected reserves and features as well as the whole public. Within the assessment, attention must be paid to the applied mining technologies as for their safety and degree of environmental impact. Highly effective technologies are preferred, minimizing the production of waste and improving the culture and sanity of miners' work. The main problem of opencast mining is the land required, impacted constructions of all types, surface water courses and reservoirs, road connections, energy and product distribution systems, undesirable changes in ground morphology disturbing the original skyline, etc. In underground mining, apart from land required, what is greatly negative is the impacts of undermining that may manifest through ground subsidence, damage to surficial structures and facilities, changes in the ground and surface water regimes including the influence to their chemism, etc. Out of the above stated, monitoring system preparation and continuous remediation of waterlogged subsidence basins is required already in the preparation stage. Moreover, in both cases attention must be paid to volume of traffic in the territory which may, in some cases, show as limiting for mining activities. At last, the issue of air pollution caused by dust from traffic, preparation plants, dumps and settling basins as well as the issue of increased noise and concussions connected with blasting cannot be neglected. It is also vital to assess the possibility and probability of critical situation occurrence, such as fire or shock bumps. Another important aspect of the assessment is the requirement for continuous expert biological monitoring of the locality (assessment of species diversity of the locality, assessment of ecosystem resistance to increasing strain, etc.), operative elimination of mining activity impacts on the ground in order to protect the fauna and flora, and provide replacement plantation in the affected sites.

The procedural environmental impact assessment process may differ in details. Table 3 shows an example of detail arrangement of EIA process in the Czech Republic.

At present, world-wide attention is paid to environmental impact assessment on the level of development concepts. This trend is very meaningful as acceptance of a certain concept has direct consequences for the implementation of follow-up projects, in the majority of cases.

For example, the concept of industrial policy of wording the basic development trends determines the types of vital raw material sources. The concept of raw material policy anticipates the focus of de- 
Table 3: ElA Chart, according to CNR Act 244/1992 Coll.

\begin{tabular}{|c|c|c|c|c|}
\hline Activity & Activity required & Arranged by & Recipient & Deadline \\
\hline PLAN & plan prepared & investor & relevant authority & \\
\hline DOCUMENTATION & documentation processed & authorized person & & \\
\hline \multirow[b]{2}{*}{ HANDOVER } & $\begin{array}{l}\text { sending of plan and docu- } \\
\text { mentation }\end{array}$ & investor & relevant authority & \\
\hline & $\begin{array}{l}\text { documentation sent to the } \\
\text { relevant municipality and } \\
\text { authorities in question }\end{array}$ & relevant authority & $\begin{array}{l}\text { relevant municipality, } \\
\text { authorities in question }\end{array}$ & 5 days \\
\hline \multirow[t]{2}{*}{ PUBLIC CONSULTATION } & $\begin{array}{l}\text { announcement on possible } \\
\text { consultation }\end{array}$ & relevant municipality & citizens & 5 days \\
\hline & public consultation & citizens & relevant municipality & 30 days \\
\hline \multirow{2}{*}{ STATEMENT } & $\begin{array}{l}\text { written comments and } \\
\text { statement }\end{array}$ & relevant municipality & relevant authority & 14 days \\
\hline & $\begin{array}{l}\text { statement to the documen- } \\
\text { tation }\end{array}$ & authorities in question & relevant authority & 50 days \\
\hline \multirow[t]{2}{*}{ EXPERT OPINION } & $\begin{array}{l}\text { arrangement of expert opini- } \\
\text { on processing }\end{array}$ & relevant authority & authorized person & \\
\hline & expert opinion processed & authorized person & relevant authority & 60 days \\
\hline \multirow{2}{*}{ PUBLIC HEARING } & public hearing & relevant authority & & 30 days \\
\hline & report compiled & relevant authority & & \\
\hline OPINION & opinion issued & relevant authority & investor & \\
\hline
\end{tabular}

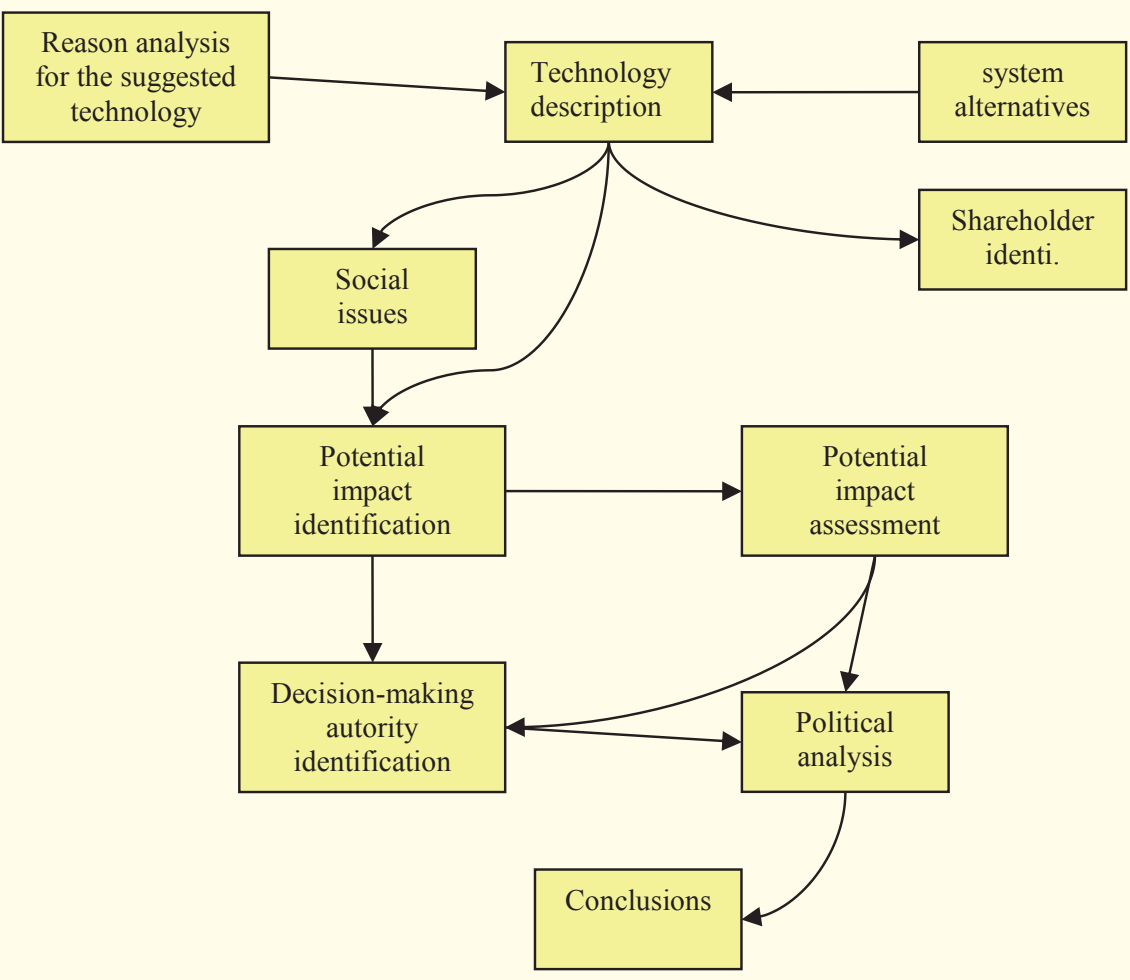

Fig. 3: Chart of ElA process, according to SRK Ltd. 


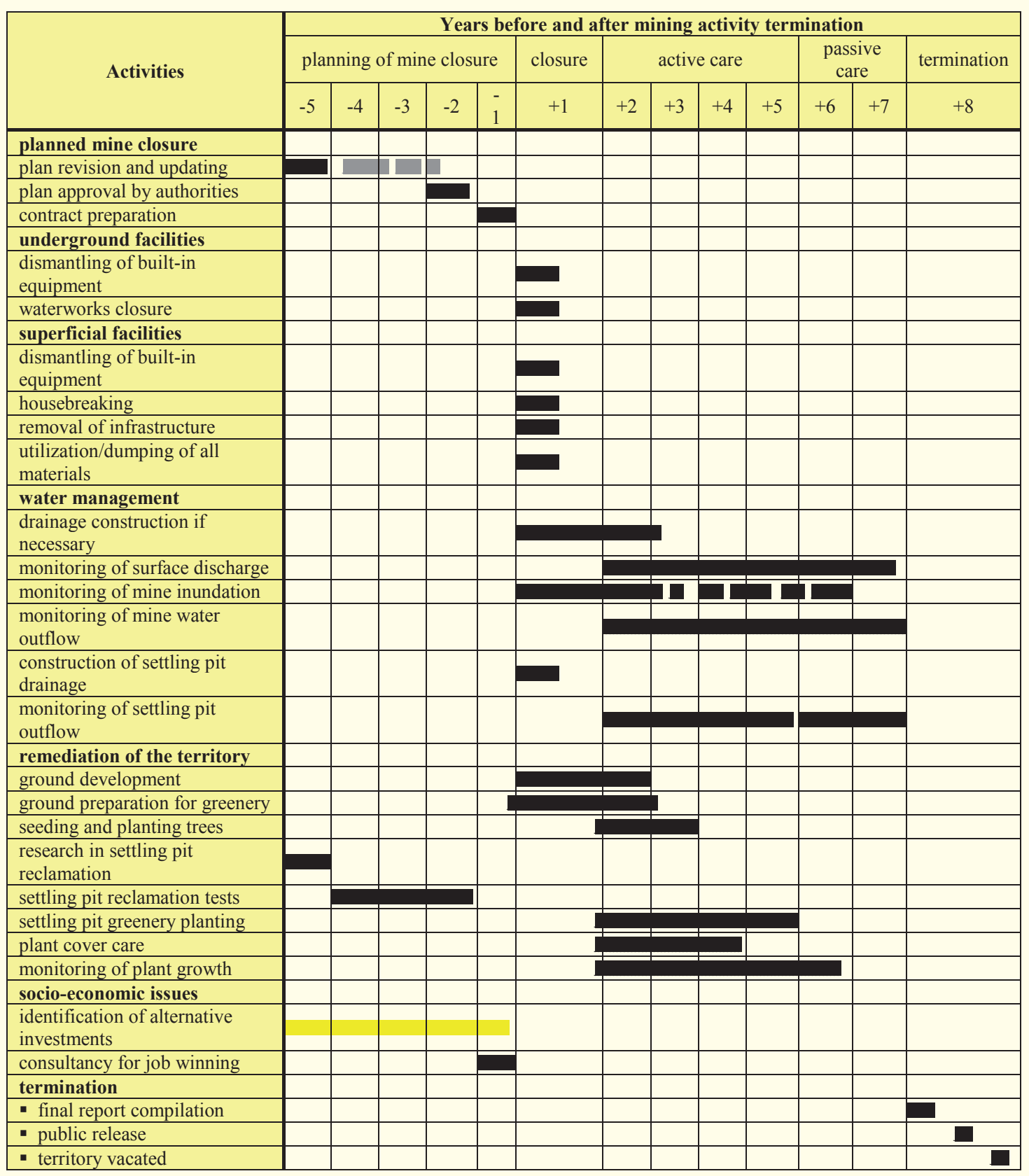

posit exploration and extraction of mineral resources, or other methods of their acquisition (e.g. by means of import or through foreign co-operation). The concept of traffic policy may have an impact on the sphere of exploration and mining as the future development of roads requires provision of necessary sources of building stone and gravel sand.
A part of assessment of project construction and mining plant operation is also the evaluation of a project of their abandonment and follow-up reclamation of the territory in question (Table 4). This part of assessment is very important as ill-conceived and objectively and financially unsecured projects may lead to consequent complications when the 
final arrangement of necessary work becomes the concern of public authorities. The existing mining laws or related environmental regulations fully control this sphere and impose the duty to create vital financial resources.

From the conceptual point of view, reclamation work is divided into several successive phases (Smolík in Dirner et a1. 1997):

- preparatory phase with its predominantly preventive and optimization function; it is grounded in the co-ordination of utilization of a raw material source and dealing with possible conflicts of interest,

- mining-technical phase when attention must be focused on minimization of mining impacts and controlled shaping of the devastated territory, especially through suitable placement of dumps and disposal sites, suitable shaping of the ground, etc.,

- biotechnical phase which, through work of technical and biological character, modifies and improves ecological characteristics of a locality according to a chosen type of land reclamation (agricultural, forestry, orchard-park, water-management, recreational),

- post-reclamation phase initiated with handing over the reclaimed land for further use.

The procedure of EnTA - Environmental Technology Assessment - designed by UNEP IE, is well applicable for the environmental assessment of mining technologies (Figure 4).

\section{Refuse from Mining and Preparation}

One of the main environmental impacts of mining and coal preparation, in particular, are settling pits for coal slurries. Settling pits cause extensive contamination of soils by toxic metals and organic pollutants, unfavourably influence the rock environment including the quality of surface and ground water, and embody vast disposal sites of coal slurries. Their combustion then causes air pollution. Air pollution is also brought about by burning of dumps.

\section{Disposal Mining}

In terms of possible reliable and relatively effective disposal of certain types of waste materials, underground mining gains another significant function, i.e. waste dumping and thus it is labelled as waste disposal mining.

\subsection{Characteristics of waste disposal mining}

In the future, waste disposal mining may signifi- cantly contribute to the environmental protection. Preferred must be benefication of waste both from mining as well as from other industrial branches for the mining purposes. This is possible in the form of building and filling materials to be used in mining. With an ever increasing need of building materials underground, this way it is possible to make use of the material advantages in the sphere of safety, rock mechanics and reinforcing technologies with longterm safe disposal of industrial refuse underground. In addition, in the long-term, waste disposal containing toxic and radioactive harmful substances may be realized in suitable rock formations below the ground. Long-term safety is guaranteed by a geological and technical system of multiple barriers. Disposal or dumping may also be carried out with the option of a repeated use, or without it, namely in conveniently fitted cavities, chambers, caverns and deep wells.

In underground deposit mining worked our space is formed underground which, for certain reasons, particularly safety ones, is filled spontaneously (surrounding rock caving) or backfilled with other material. In larger scales, the use of backfill is nowadays mainly required by safety and ecological causes. Mining and non-mining waste is used as backfill material. Backfilling the worked out or other free space in underground mining of mineral resources offers advantages independent of economy, both in terms of safety (reaching more efficient ventilation and more favourable climatic conditions) as well as ecology (protection of surficial and landscape structures). Advantages even multiply if waste disposal is possible this way, which would otherwise cause problems in the environmental sphere. This again raises an idea of creating and using underground space for this purpose - to dispose of harmful substances. In mining the issue of waste disposal is continuously growing on importance, namely in the way the classical backfilling of worked out space is completed with utilization and follow-up dumping of ecologically unsound waste in the existing underground space, or underground space specially established for the purposes. If waste disposal through backfilling is the basic and only reason of mining, new aspects, tasks and problems appear there

\subsection{Reasons and preconditions for underground waste disposal}

The current situation of waste production, of hazardous waste in particular, is alarming in the pro- 
duction, social and consumers'spheres of the Czech Republic. This unfavourable situation, mainly in respect to immediate possible changes in own production technologies that would lead to a radical turn in waste management (volume minimization, recycling, secondary utilization, etc.), demands an immediate search for paths how to limit or exclude contact of already generated and ongoingly formed waste.

The today's economic perspective and economic policies are unfavourable for dealing with waste issues and the only hopeful process may be a very economical and financially undemanding one in the near future. This logically ensues a possible solution only for some, let's say, simpler and easier problems of waste management.

There are sufficient reliable and verified details, gained through long-term geological-exploratory and mining activities, on the fact that that within the Czech Republic there are territories with suitable conditions. It may be an effective solution of a basic problem in the given space and time, i.e. construction of ecologically suitable disposal sites of regular and hazardous waste in appropriate geological, hydrogeological and geotechnical conditions making use of existing capacities or abandoned underground mines. This way operation of underground disposal sites shall be possible on current worldwide level as a prospective activity in the mining business. This procedure is characterized by current requirements and expected results in the future:

a) Favourable rock environment is the most effective safety barrier, object placement underground practically excludes an access of unauthorized personnel and action of surficial effects (changes in temperatures, solar radiation, high precipitation, etc.).

b) Conversion of selected mining capacities into long-term disposal site operation, prospectively long-term waste disposal sites underground value up already expended and largely written-off investments if main development mine workings, roads and facilities, energetic, filling and ventilation systems are concerned.

c) Activities in the rock environment are a specialized profession for a narrow circle of workers with formed habits for staying and working underground. Nowadays, mining and underground construction have available suitable technical means and technologies to create new space in the rock massif without excessive disruption of the rocks in the surrounding breaking.

d) Construction and operation of underground storage and disposal sites maintains jobs for specialized professions and skilled workers. e) Transition from extraction to waste disposal mining is time less demanding than construction of new premises on the ground.
Construction and operation of disposal sites making use of existing capacities does not make demands on land required on the ground, does not require construction of new power and media supplies, building of new roads, does not strain the environment by other unfavourable impacts such as noise, dustiness, etc.

One of the steps leading to system, technically well-arranged and safe procedure in design, establishing and operation of underground disposal sites of various types of waste is processing of fundamental technical conditions for waste dumping underground, such as standards that must have the following targets:

1) to determine a uniform framework to deal with specific cases and ensure complexness of solutions,

2) to ensure system approach to set up and operate waste disposal sites underground,

3) to create basis for processing normative documentation of a higher degree,

4) to provide professional and lay public with proofs on reliability and safety of the suggested structures and facilities for waste dumping underground,

5) to elaborate and introduce effective tools for environmental protection (audits, assessment methodology, etc.).

\subsection{Conceptual approach to dealing with underground waste disposal issue}

Apart others, an approach to utilization of underground space depends on the fact which mine space can be taken into account and what type of waste will be dumped there. In principle, the extent of utilization includes areas from separate sections of active mines, via abandoned mining plants to new disposal site operations. Naturally, costs increase respectively. As the need of new underground space for waste disposal will be great, it is requisite to state several comments on the concept of new space formation and the own waste disposal technology, to start with.

Above all, construction of waste disposal sites underground must be implemented taking into account long-term safety and not the quantity of dumped material.

Therefore, the aspect of optimal geometric parameters of mine workings has a great significance for the disposal process. A solution depends on the considered type of waste disposal area, waste structure and dumping method. The type of disposal area is determined by the fact whether the disposal site is established for repeated utilization of the waste or without it. Only solid or reinforceable loose materials and slurry waste should be used for dumping. 
The dumping technology depends on waste processing, namely by pumping, bulking or stacking for unprocessed, modified or packed waste. Currently, for example in Germany they are in the stage of trial runs or operations of such underground disposal site types: chambers of salt mines, horizontal mine workings and suitably modified wells.

\section{Assessment of Natural Conditions for Waste Disposal Mining}

Natural conditions include geological structure and massif structure, hydrogeological conditions and geomechanical assessment of selected rock positions or the individual rock types with respect to primary massif stress-deformation state and the state brought about by mining activities. Other factors are also important: petrographic composition, stage of diagenesis and physical- mechanical properties of rocks.

\subsection{Geological structure of the massif}

In terms of geology, goal-directed and careful attention must be paid to the issue of waste dumping - it is the case of basic questions on the massif structure as a whole, structure and position of specific rock positions (positions of water-bearing horizons and positions of stratification insulants) and tectonic conditions. As for overall mode of deposition an important factor is the depth of deposit placement or position where waste disposal site will be situated. Geological environment acts as an effective barrier against the spread of contaminants and isolates such substances from the biosphere.

The effectiveness of the geological environment is given by the ability to prevent the flow of ground water in the disposal site vicinity and to reduce possible migration to minimum this way. The geological structure predetermines the geochemical conditions in the disposal site vicinity and conditions the hydrogeological regime, including the ground water quality. Ground water may contain certain elements, in dependence on the rock petrographic composition, stimulating corrosion of packing materials or support other processes.

For assessment, tectonic conditions are very important as they significantly influence the hydrogeological regime of the rock massif and determine the initial character of primary massif stress-deformation state.

\subsection{Hydrogeological conditions}

The study of hydrogeological conditions is one of the basic preconditions of underground dumping solution. For example, in the Ostrava-Karviná District in the superincumbent and coal measures several water-bearing horizons exist that may be with gas zones $\left(\mathrm{CH}_{4}, \mathrm{CO}_{2}\right)$. In principle, it is the case of a water-bearing subterranean horizon in the Quaternary, two to three water-bearing sandy horizons in the Tertiary containing mineralized confined water, water-bearing horizon of basal clastics on the boundary of the Tertiary and Carboniferous, called the Ostrava-Karviná detritus, manifesting various thicknesses and depths of occurrence, water-bearing zones and crevisse water in the Carboniferous contains mainly mineralized water of various composition and tension.

An operated mine shows water inflows which must be constantly drawn off. Apart from the mentioned sources, process water is also meaningful.

When a mine is in operation, the so-called steady water inflow is formed all the time. Due to permanent changes in workplaces in mine workings water inflow into a mine may considerably vary especially transferring into other areas. The situation is different when a mine is to be abandoned.

In the final stage of mine abandonment, having stopped pumping, gradual inundation of the worked space occurs. These are in particular, cross drifts, roads, spatial mine workings (depot, engine halls, power transformation substations, engine depots, etc.) and old workings. The rate of inundation and water rise depend on the quantity of inflowing water, volume of the free space in the mine and its horizontal and vertical distribution. Water inflow into a mine can be quite reliably determined from operation documentation. It is more difficult with estimating the volume of inaccessible flooded space. Long mine workings, whose total length reaches several hundred kilometres, are more or less suppressed or caved, old workings in the worked out sections are filled with caved broken rock or backfill. The volume of free space to be filled with water can be determined only roughly and thus also the estimated course of inundation, in particular a rise of water level can fluctuate a lot.

\subsection{Petrographic composition, physical and mechanical properties of rocks}

Both in the enclosing rock as well as coal mass compression strength, mass density and bulk density, porosity, modulus of elasticity, total elastic energy and speed of ultrasonics spread are identified. 


\subsection{Geomechanical assessment of the massif}

Deformation and disruption of the rock massif in mining activities depend on the geological structure of the massif, including the structurally geological structure of the massif and petrographic composition of rocks, physical-mechanical properties of rocks, primary stress field given predominantly by a gravitational field and field of primary tectonic stress and finally, secondary induced stress field forming through rearrangement of primary stress due to mining activities. The individual factors form separate units with it, but they are also mutually interrelated and influence one another. For instance, primary stress fields are affected by both the geological structure as well as by physical and mechanical properties of rocks.

Mechanical properties of rocks depend on their petrographic structure, age (consolidation), structure and other geological factors. In the end, also induced stress fields are a function of not only distribution of mine workings in time and space but of the geological structure and mechanical properties as well.

Dealing with the issues of deformation and disruption of the massif it is necessary to build on a detailed geological cognition of the territory in question, physical and mechanical properties of rocks and assessment of primary and secondary stress fields and their changes in the interest part of the massif.

\subsection{Evaluation of geochemical conditions}

The locality must be assessed in terms of geochemistry. It is vital to take into account the issue of geochemical stability of water-air-rock phase interface, i.e. parameters affecting the rate of rock environment weathering, type of secondary transformations, sorptive capacities, and functions of geochemical barriers. Interactions between the identified rock types, water types and expected waste material must also be considered. An analysis of dissolution of loose and crushed material in an enclosed system is carried out and next, an identical process in the flow through system is monitored. The surroundings of the prepared disposal site may be strained thermally. An idea of reaction of the rock massif on the thermal changes can be obtained from the so-called thermal test. A very important value to assess the stability of the disposal site is a detail on the rock massif stress-deformation state and its changes in time.

\section{References}

[1] Dirner V., Gondek H.: Underground waste dumping. Mezinárodní konference „3rd Mining and Environmental protection. Yugoslavia 2001, str.123-128

[2] Dirner V.: Some Aspects of Underground Waste Dumping. The 15th International Conference „Ecology and Baltic Sea Region's Countries Development" kronshtadt-Kotka, 2000, pp.195-199

[3] Ministerstvo životního prostředí. Životní prostředí České republiky. 1. vyd. Praha: Academia 1990. Nerostné suroviny a geofaktory s. 87-98 ISNB 80-200-0292-8

[4] Dirner V. (2000): Die legislative Aspekte des Abfalwirtschafts in der Tschechien. Mezinárodní konference „Zneškodňovanie a uskladňovanie odpadov v zemskej kôre a podzemných priestoroch" F-BERG Košice, HGF Ostrava, HB Prievidza. 10.-12.5.2000 Vyšná Boca. S.124-130.

[5] Dirner V., Smrž V. (1997): Evaluation of prevention in deep mines in the light of modern measuring methods, sborník mezinárodní vědecké konference „MPES '97",Balkema Rotterdam (975-978 p.).

[6] Institut regionálních informací: Těžba a ochrana ložisek nerostných surovin [on line]. [cit. 2009-03-24]. Dostupný z WWW: <http://www.iri.cz/vuc/plzen-navrh/zprava/kapitoly/B05,4.htm>

[7] Ministerstvo životního prostředí: Horninové prostředí [on line]. [cit. 2009-04-14]. Dostupný z WWW: <http://www.env. cz/AIS/web-pub.nsf/\$pid/MZPJKF4L7A4R>

[8] Vysoká škola báňská - Technická univerzita Ostrava: Problematika dobývání a ukončování hornické činnosti na dolech a lomech [on line]. [cit. 2009-06-12]. Dostupný z WWW: <http://www.hgf.vsb.cz/kat542/Seminar_3/Index. htm>

[9] Státní Báňská správa: MSp ČR [on line]. [cit. 2009-06-26]. Dostupný zWWW: < http://www.cbusbs.cz/projekty.aspx >

[10] Pech, K. Dirner, V. Bláhová, O.: Ochrana životního prostředí, skripta VŠB-TU Ostrava 1997

[11] Neset, K.: Vlivy poddolování, SNTL Praha 1984

[12] Matouš, J. Novák, J.: Vlivy poddolování a ekologie hornické krajiny In Sborník referátů z konference Doly a životní prostředí, Haviŕov 1989.

[13] Dirner, V.: Těžba nerostných surovin a problematika odpadového hospodářství, Sborník referátů z Mezinárodní vědecké konference VŠB-TU Ostrava 1995. 